\title{
Attempts at active protection of Inonotus obliquus by inoculating birches with its mycelium
}

\author{
JACEK PIĘTKA and ANDRZEJ GRZYWACZ \\ Department of Mycology and Forest Phytopathology,Warsaw Agricultural University \\ Nowoursynowska 159, PL 02776 Warszawa \\ jacek_pietka@sggw.pl, andrzej_grzywacz@sggw.pl
}

Pięt ka J., Grzywacz A.: Attempts at active protection of Inonotus obliquus by inoculating birches with its mycelium. Acta Mycol. 41 (2): 305 312, 2006.

Practical application of active protection methods of Inonotus obliquus (Fr.) Pilát. was examined. Thirty live birches and 15 birch stem sections were artificially inoculated with the fungal mycelium in the Mińsk Forest District (E Poland). The mycelium of I. obliquus was not recorded in the felled test trees and birch stem sections upon the completion of the experiment. Artificial introduction of I. obliquus in the natural environment faces significant problems caused by strong competition from other birch wood decay fungi. As in vitro studies show (individual biotic effect determination), the fungi examined, occurring on birch trees in nature, are dominant species in relation to I. obliquus.

Key words: active protection, Inonotus obliquus, tree inoculation, liginicolous fungi, birch, competition

\section{INTRODUCTION}

Inonotus obliquus (Fr.) Pilát is a fairly rare parasitic fungus developing primarily on birch trees: Betula pendula, B. pubescens, B. carpatica, as well as infrequently on maple trees: Acer campestre, A. pseudoplatanus, alder trees: Alnus glutinosa, A. incana, oak trees: Q. cerris, Q. petraea, ash trees Fraxinus excelsior, elm trees Ulmus, beech trees Fagus, poplar trees Populus, rowan trees Sorbus, hophornbeam trees Ostrya (Kotlaba 1984; Semenkova, Sokolova 1992; Ryvarden, Gilbertson 1993; Zabel 1947). In Poland, where it decays almost exclusively birch wood, the fungus seems to be more common in Podlasie, including the Białowieża Forest, as well as in Masuria and Great Poland (Mańka, Stube 1952; Domański 1965). It is considered to be rare in Upper Silesia (Wojew od a 1999) and the Góry Świętokrzyskie Mts. (Łuszczyński 2002). Outside Europe, it is also encountered in Asia and North America (Canada, USA) (Kotlab a 1984). 
The fungus causes extensive white rot of wood, most often infecting trees aged 30-50. Infection of healthy trees occurs through wounds, knots, frost shakes. After a few years, the parasite produces vegetative fruitbodies (sterile conks): irregular black lumps (knobs, growths) on live trees, usually in the place of the initial infection. The parasite may develop on a trunk for 30-80 years (Černý 1976). Fruitbodies may weigh up to 3-5 kg after 10-15 years (Gammerman et al. 1975), and specimens as heavy as $16 \mathrm{~kg}$ have been reported (Sin adskij 1973). The diameter of old fruitbodies on thick old trees may even reach $0.5 \mathrm{~m}$ (D o mański 1965), their thickness - 10-15 cm, and length - 1-1.5 m (G a m m e r m an et al. 1975). The surface of the sterile conk is strongly cracked, very hard, brittle, black, as if charred; its flesh is also hard, brown, with yellowish discolouration. Numerous chlamydospores that enable infection of other trees develop inside the sterile conk until the host's death (Domański 1965). The fungus was for a long time considered to be a sterile form of Fomes igniarius f. sterilis Van. (Phellinus igniarius f. nigricans (Fr.) Bond.) (Va n in 1955).

In Poland, sterile conks most often occur on birch trunks up to $9 \mathrm{~m}$, in all the directions of the world, preferring, however, the north, north-east and north-west: fruitbodies develop best on the less insolated side where humidity conditions are more favourable. More vegetative fruitbodies were recorded in older age class treestands, and the dimensions of individual collected specimens were greater on trees with a bigger mean diameter at breast height (dbh) (Przesław 1985).

Resupinate generative fruitbodies appear when the tree is dying or after it has died, under the bark of standing or lying trees. Such fruitbodies occur only once in August - September, always on the trunk side where the rot is most advanced, often in the place of sterile conks or where their remnants are visible (Č e r ný 1976). Generative fruitbodies sometimes reach very big dimensions: $3-4 \mathrm{~m}$ long and up to $50 \mathrm{~cm}$ wide (Bond arceva, Parm as to 1986). Their margin is usually thicker (2.5-4 mm), and forces the bark apart from the wood, allowing the fruitbody to expand. Tubes are always positioned obliquely to the substrate, usually at 20-30을 (hence the species name). Young tubes are yellow-olive, older - rusty-brown. Pores are polygonalspherical, often elongated, 3-4 in $1 \mathrm{~mm}$ (D o m a ńs ki 1965). Insects often quickly eat generative fruitbodies, making it difficult to find them (Ryvarden, Gilbertson 1993). In the US, I. obliquus produced a generative fruitbody on an infected beech tree (Fagus grandifolia) that was still alive (Zabel 1947).

An appropriately prepared extract from sterile conks has medicinal properties. It was used in cancer, intestinal pains, hyperacidity, gastric and duodenal ulcerations, spleen and liver disorders, and applied externally in the inflammation of the oral cavity and reproductive organs (Pi askowski 1957; Oża rowski 1980; Grochowski 1992). In the former states of the Soviet Union, it is still used extensively in several disorders. A number of medicinal products, including Befungin and Binczaga, thickened fungal extracts with added cobalt salt, were prepared at the Leningrad Botanical Institute. The fungus has a favourable effect on the central nervous system and metabolic processes, and boosts immunity to infections. Aqueous extracts have been shown to greatly alleviate the suffering in cancer patients, relieve pain, improve appetite; it is not, however, a radical drug in malignant cancer cases, although it inhibits the development of the disease if used at its initial stages (S a u tin et al. 1984). 
Sterile conk infusions are drunk instead of tea in Siberia (Cartwright, Findlay 1951; S a ut in et al. 1984).

I. obliquus parasitizes various deciduous trees; only fruitbodies on birch trunks, however, have medicinal properties. They may be collected throughout the year; winter and early spring are most convenient as it is easier to find sterile conks on leafless trees (S a u tin et al. 1984).

I. obliquus is one of the 20 fungal species to be monitored in Poland within the National Environmental Monitoring programme adopted in May 1992. Selected also because of its medicinal properties, the fungus may be noticed and recognised easily in the field by non-specialists (Grzywacz et al. 1997; Ław ry nowicz 2000). It is red-listed as R (rare) on the "Red list of macrofungi in Poland" (Wojew oda, Law ry now icz 2006). It is partially protected pursuant to the regulation of the Minister of the Environment of 2004 on protected species of wild-growing fungi; fruitbodies may be acquired only with the voivode's permission (Dz. U. 2004.168.1765).

The aim of this study was to examine practical application of active protection methods and to artificially cultivate I. obliquus, a species with medicinal properties, which has been excessively exploited and is now disappearing and becoming increasingly rare. The feasibility of artificial infection of live trees and dead birch wood with the mycelium of I. obliquus, acquired in natural conditions and cultivated in laboratory conditions, was examined. Biotic relationships between I. obliquus and selected fungi occurring on birch trees were investigated to assess the competition degree and their inhibitory function.

\section{MATERIALS AND METHODS}

A sterile conk of I. obliquus was obtained from a live birch tree, Betula pendula $(\mathrm{dbh} 26 \mathrm{~cm})$, growing in a tree-stand in the Mińsk Forest District (E Poland). The fruitbody, $8 \mathrm{~cm}$ wide, $8 \mathrm{~cm}$ long and $12 \mathrm{~cm}$ tall, was cut out with a large wood fragment and transported to the laboratory of the Department of Mycology and Forest Phytopathology, Warsaw Agricultural University, where a pure mycelium culture was isolated from fragments of infected wood directly beneath the fruitbody.

The individual biotic effect (IBE) determined using plate tests. Petri dishes $7 \mathrm{~cm}$ in diameter with agart-wort medium were used. Two fungal species were inoculated $2 \mathrm{~cm}$ apart in the central part of each plate: I. obliquus and a fungus belonging to a specific community (competitive species). Competitive species were substituted in successive tests, repeated 10 times; the fungus examined was used in each test. Competitive species and I. obliquus were also inoculated separately, each variant repeated 5 times. The mutual influence of I. obliquus and the fungi occurring in the same trophic environment, weakened birch trees and dead wood (stem sections, stumps), was examined in the experiment, i.e.: Daedaleopsis confragosa, Fomes fomentarius, Fomitopsis pinicola, Lenzites betulina, Piptoporus betulinus, Trametes versicolor.

Pure fungal cultures from the collections of the Department of Mycology and Forest Phytopathology were used. Plates were incubated in a Heraeus incubator at $22^{\circ} \mathrm{C}$. Monocultures and dicultures were measured after 10 days. The development of dicultures served to determine the "individual biotic effect", using the evaluation scale established by Mańka (1974). As given in the method, a positive IBE shows an inhibiting influence. 
Artificial infection of stem sections and trunks in natural sites. A field experiment was established in September 1999: birch stem sections and selected, healthy birch trees were inoculated. In the first part of the experiment, the wood of a felled birch was cut into stem sections, $60 \mathrm{~cm}$ long, and left to dry. After 11 days, they were inoculated at the height of $30 \mathrm{~cm}$, on 4 sides, with birch wood inocula, $30 \times 5 \times 5 \mathrm{~mm}$ (50\%), and parts of Sambucus nigra shoots (50\%) overgrown with the mycelium of I. obliquus. The procedure was used as the mycelium of I. obliquus colonised dead birch wood inocula less intensively while it easily overgrew the stems of $S$. nigra shoots. The inoculated stem sections (15 pieces) were placed in two rows under the crowns of fruit trees, slightly sinking their lower parts in the soil. The experiment was established in a plot in the village of Maliszew near Mińsk Mazowiecki.

In the second part of the experiment, 30 live birches were inoculated in the Mińsk Forest District (section 317 a), in the vicinity of the Cegłów-Podskwarne road. As specified in the Forest Management Plan of the Mińsk Forest District (1996-2005), the birches were 69 years old. They were inoculated at two levels, 2 and $3 \mathrm{~m}$, in the four directions of the world. Inocula consisting of $S$. nigra shoots overgrown with the mycelium of I. obliquus were used at $2 \mathrm{~m}$ while birch wood inocula overgrown with the mycelium were used at $3 \mathrm{~m}$. The mean dbh of the inoculated birches was 35.5 $\mathrm{cm}$. The trees were marked permanently with galvanised iron plates. The permission of the Head Forester in the Mińsk Forest District was obtained to establish the experiment.

Holes $10-12 \mathrm{~cm}$ deep and $8 \mathrm{~mm}$ in diameter were drilled with a battery drill. One inoculum was introduced into each hole with tweezers and closed up with freshly obtained shoots of Corylus avellana.

The experiment was terminated in 2002. The stem sections were split along the line delineated by the places of visible inlet holes. Wood fragments, appropriately labelled and packed in paper envelopes, were transported to the laboratory. Two live inoculated trees were also obtained. Two one-meter long trunk sections were made from each birch tree (from the height at 1.5-2.5 $\mathrm{m}$ and 2.5-3.5 m) and transported to the laboratory where they were split. The initial inoculum was removed in the inoculation chamber. Wood samples were collected at $1 \mathrm{~cm}$ from the inoculation point and placed on agart-wort medium in Petri dishes. If visible rot was observed, the wood was sampled at successive distances along the trunk axis every $2 \mathrm{~cm}$.

\section{RESULTS}

The findings show that I. obliquus is inhibited by the birch wood-decay fungi examined (Tab.1). The individual biotic effect is influenced mostly by competition. The inhibition zone was not recorded in any experiment variant.

The highest IBE index $\quad+5$ was recorded for $L$. betulina and the lowest (IBE +2 ) for D. confragosa.

The results of artificial inoculation of trees and stem sections with the mycelium of I. obliquus were examined in October 2002, 3 years after the experiment had been established.

Fruitbodies of the following fungal species were observed on the 15 birch stem sections: Trametes versicolor on 9 stem sections, Stereum hirsutum on 3 stem sections, 
Table 1

Influence of selected fungal cultures colonising birch wood on the development of the mycelium of I. obliquus

\begin{tabular}{|l|l|c|}
\hline \multicolumn{1}{|c|}{ Fungal species } & \multicolumn{1}{|c|}{ Rot type } & \multicolumn{1}{c|}{$\begin{array}{c}\text { Individual biotic } \\
\text { effect (IBE) index }\end{array}$} \\
\hline Daedaleopsis confragosa & white & +2 \\
\hline Fomes fomentarius & white & +4 \\
\hline Fomitopsis pinicola & brown & +4 \\
\hline Lenzites betulina & white & +5 \\
\hline Piptoporus betulinus & brown & +4 \\
\hline Trametes versicolor & white & +4 \\
\hline
\end{tabular}

Bjerkandera adusta on 3 stem sections. I. obliquus was not isolated in the laboratory from the birch stem sections artificially infected with its mycelium.

Two trees were additionally felled in the study area in the Mińsk Forest District (tree no 19, dbh $29 \mathrm{~cm}$; tree no 24, dbh $28 \mathrm{~cm}$ ). The felled birches had distinct star false heartwood, whose arms overlapped with the inlet hole points through which the inocula had been inserted (Figs 1,2). Re-isolation of the mycelium of I. obliquus from these trees failed. A big participation of moulds and the mycelium of undetermined basidiomycetes (hyphae with clamp-connections) was, however, observed during the isolation on media in Petri dishes. The visible star heartwood in birch no 19 stretched from the height of $0.5 \mathrm{~m}$ up to $5.7 \mathrm{~m}$ while it was still slightly visible at the level of the felling (ca. $10 \mathrm{~cm}$.) and reached up to $6 \mathrm{~m}$ in birch no 24 .

\section{DISCUSSION}

The mycelium of I. obliquus was not reisolated from either the stem sections or live trees after the 3 years of the experiment. Fruitbodies of some other fungal species were recorded on the stem sections: Trametes versicolor, Stereum hirsutum, Bjerkandera adusta. This seems to confirm the claim that I. obliquus develops exclusively on live trees. Dead birch wood was thus naturally colonised by common saprotrophic species.

Distinctive, dark-coloured star false heartwood whose arms overlapped with inlet hole points was recorded in the felled test trees. Krzysik (1974) claims that false heartwood occurs as a result of the penetration and destructive activity of fungi or external factors such as heavy frost or air penetration, and notices that heartwood is irregular or star-like in the areas adjacent to air penetration points. Heartwood compounds that are products of the dying parenchymal cell content penetrate vessels and adjacent tissues, producing brown discolouration (Krzysik 1974). As observed during laboratory trials to re-isolate the mycelium of I. obliquus, other undetermined basidiomycetes (clamp-connections visible on the mycelium) that may have contributed to the development of false heartwood were recorded. Other fungal spores may also have penetrated the trunk when the experiment was established or later through the inlet holes. Having germinated, they found good development conditions and inhibited the growth of the mycelium of I. obliquus. Pięt ka and Grzywacz (2005) report that positive effects were obtained in an experiment in which live old larches 
were inoculated with the mycelium of Fomitopsis officinalis. An active mycelium was observed in both felled test trees after 3 years of the experiment. A strong resin reaction of the inoculated larches was observed on the day when the experiment was established. An outward resin leak from the sapwood was advantageous as the inlet hole was sealed up and potential infection by other organism was limited.

Visible false heartwood in the felled birches reached from ca. 0.1-0.5 m (1.5-1.9 m downwards from the level of the lowest holes) to $5.7-6 \mathrm{~m}$ (2.7-3 $\mathrm{m}$ upwards from the highest holes), which shows that it occurs significantly more quickly up the trunk.

The IBE results (Tab. 1) of various birch wood-decay fungi show that I. obliqu$u$ s is an inhibited species. Laboratory examinations (on agar-wort medium in Petri dishes) show that fungal competition yields relatively clear results; the results of these examinations, however, may not always be applied to relationships between these fungi in natural conditions, on a specific host plant. Schwarze et al. (2000) report that the infection success depends on a number of factors: parasitic abilities of the fungus, tree vitality, type and size of the injury, environmental factors (such as temperature, humidity, oxygen content in the substrate), pathogen's morphological specialisation. It should also be remembered that some fungal species exhibit strain diversification, exhibited in the value of the IBE, as observed by Mańk a (1999) or Tyszkiewicz and Mańka (1999).

The infection success is affected not only by competitive fungi of the class Basidiomycetes but also by a number of other fungi (moulds, fungi causing wood stains) and bacteria. Only detailed examinations of the quantitative and qualitative structure of the fungal communities colonising knots and mechanical injuries of the birches would help determine the actual function of these communities in relation to $I$. $o b$ liquus and to assess potential successful infection. It may be supposed, however, that the inhibition of the I. obliquus mycelium growth in laboratory examinations by other basidiomycetes encountered on weakened birches may to some extent contribute to the number of successful infections by this fungal species in nature.

It may not be definitely concluded that the mycelium of I. obliquus did not colonise the other birches, artificially infected in this experiment. Sterile conks may in the future become visible on the other test trees in the birch wood in the Mińsk Forest District, which would help assess the success rate of active protection methods of this fungus be means of artificial infection of live trees.

Acknowledgements. We are grateful to Dr. Andrzej Szczepkowski for his assistance in establishing the experiments and collecting research material.

\section{CONCLUSIONS}

1. As a parasitic species that colonises only live trees in nature, Inonotus obliquus did not colonise artificially infected birch stem sections. It was primarily colonised by the following species: Trametes versicolor, Stereum hirsutum, Bjerkandera adusta.

2. Attempts to artificially introduce Inonotus obliquus to the natural environment face great problems caused by strong competition from other birch wood-decay fungi. The results of individual biotic effects show that Inonotus obliquus may lose the competition for the nutritive basis (weakened birches) with fungi occurring in nature. 
3. The recorded false heartwood in the test trees developed almost twice as fast up the trunk from the inlet hole points.

4. The examinations conducted show that given the current knowledge on the subject there are no practical possibilities of active protection of Inonotus obliquus. Other methods of artificial inoculation of birches should be devised. The mycelium may be stored as pure cultures in a laboratory.

\section{REFERENCES}

Bondarceva M. A., Parmast to É. Ch. 1986. Opredelitel' gribov SSSR. Porjadok Afilloforovye. Le ningrad, Nauka.

Cartwright K. S. G., Fin dlay W. P. K. 1951. Rozkład i konserwacja drewna. PWRiL, Warszawa.

Če r ný A. 1976. Lesnická fytopatologie. Státni zemědělské nakladatelstvi, Praha.

Domański S. 1965. Flora Polska. Grzyby (Fungi) 2: Basidiomycetes. Aphyllophorales. Polyporaceae I. Mucronoporaceae I, PWN, Warszawa.

Dz.U.2004.168.1765. Rozporządzenie Ministra Środowiska z dnia 9 lipca 2004 r. w sprawie gatunków dziko występujących grzybów objętych ochroną.

Gammerman A. F., Kadaev G. N., Šupinskaja M. D., Jacenko Chmelevskij A. A. 1975. Lekarstvennye rastenija. Vysšaja Škola, Moskva.

Groch owski W. 1992. Włóknouszek ukośny w przyrodzie i medycynie. Głos Lasu, 12: 2829.

Grzywacz A., Bujakiewicz A., Ławrynowicz M., Wojewoda W. 1997. Monitoring przyrody żywej. Grzyby wielkoowocnikowe. Warszawa, (msc.).

Kotl a b a F. 1984. Zeměpisne rozšiřeni a ekologie chorošu (Polyporales s. 1.) v Československu. Acade mia Praha.

Krzysik F. 1974. Nauka o drewnie. PWN, Warszawa.

Ławryn owicz M. 2000. Podstawy monitoringu grzybów w Polsce (In:) M. Lisiewska, M. Ławry n owicz (eds). Monitoring grzybów. Polskie Towarzystwo Botaniczne, Poznań Łódź: 915.

Łuszczyński J. 2002. Preliminary red list of Basidiomycetes in the Góry Świętokrzyskie Mts (Poland). Polish Botanical Journal 47 (2): 183193.

Mań ka K., St u be T. 1952. Występujący na brzozach grzyb Poria obliqua (Pers.) Bres. i jego rozwój na sztucznych pożywkach. Acta Soc. Bot. Pol., 21: 517536.

Mańk a K. 1974. Zbiorowiska grzybów jako kryterium oceny wpływu środowiska na choroby roślin. Phy topathologia Polonica. Zeszyty Problemowe Postępów Nauk Rolniczych, PWN. 160: 9135.

Mań k a M. 1999. Taksonomia i fitopatologiczna funkcja saprofitycznych grzybów glebowych środowiska leśnego. Zeszyty Naukowe AR w Krakowie, 63.

Ożar ow ski A. (ed.) 1980. Ziołolecznictwo. Państwowy Zakład Wydawnictw Lekarskich, Warszawa.

Pi a sk ow ski S. 1957. Wstępne badania nad otrzymywaniem i zastosowaniem preparatów z czarnej huby brzozowej w przypadkach nowotworów złośliwych u ludzi. Sylwan CI, 10: 512.

Piętka J., Grzywacz A. 2005. In situ inoculation of larch with the threatened wood decay fungus Fomitopsis officinalis (Basidiomycota) experimental studies. Polish Botanical Journal 50 (2): 225 231.

Przesław B. 1985. Biologia włóknouszka ukośnego (Inonotus obliquus) i jego występowanie w drzewo stanach brzozowych. Master's thesis (msc.). Katedra Ochrony Lasu i Ekologii SGGW, Warszawa.

Ryvarden L., Gilberts on R. L. 1993. European Polypores. Part 1,2. Fungiflora, Oslo.

Sa ut in V. I., Fom in a V.I., Valova Z.G. 1984. Dary našich lesov. Izdatel'stvo Polymja, Minsk.

Schwarze F. W. M. R., Engels J., Mattheck C. 2000. Fungal Strategies of Wood Decay in Trees. Springer Verlag, Berlin, Heidelberg, New York.

Semen kova I. G., Sokolova É. S. 1992. Lesnaja fitopatologija. Ékologija, Moskva.

Sin a dskij J. V. 1973. Bereza eë vrediteli i bolezni. Izdatel'stvo Nauka, Moskva.

Tyszkiewicz Z., Mańka M. 1999. Wpływ zbiorowisk grzybów glebowych dwu grądów na wzrost in vitro potencjalnych patogenów korzeni drzew. Zeszyty Naukowe AR w Krakowie 63.

Vanin S. I. 1955. Lesnaja fitopatologija. Goslesbymizdat, Moskva Leningrad.

Woj e w o d a W. 1999. Czerwona lista grzybów wielkoowocnikowych Górnego Śląska. Raporty Opinie 4, Centrum Dziedzictwa Przyrody Górnego Śląska. 3. Katowice 
Wojewoda W., Ławrynowicz M. 2006. Red list of macrofungi in Poland. (In:) Z. Mirek, K. Za rzycki, W. Wojewoda, Z. Szeląg (eds). Red list of plants and fungi in Poland. W. Szafer Inst. Bot., Pol. Acad. Sci., Kraków: 5570.

Zabel R. A. 1947. Poria obliqua on dying beech. Phytopathology 37: 189190.

\section{Próby ochrony czynnej Inonotus obliquus przez szczepienie brzóz jego grzybnią}

\section{Streszczenie}

Błyskoporek podkorowy (włóknouszek ukośny) Inonotus obliquus (Fr.) Pilát. to niezbyt częsty grzyb pasożytniczy rozwijający się w Polsce przede wszystkim na brzozach, powodując rozległą białą zgniliznę drewna. Po kilku latach sprawca wytwarza na żywych drzewach, z re guły w miejscach pierwotnej infekcji owocniki wegetatywne, przybierające kształty nieregular nych czarnych brył (guzów, czyrów).

Odpowiednio przyrządzony wyciąg z owocników wegetatywnych wykazuje właściwości lecznicze. W wielu krajach do tej pory owocniki te stosowane są bardzo szeroko, na wiele różnych schorzeń. I. obliquus w 2004 roku objęty został w Polsce ochroną częściową, znajduje się również na „Czerwonej liście grzybów wielkoowocnikowych zagrożonych w Polsce”, gdzie zapisany jest w kategorii $\mathrm{R}$ gatunków rzadkich.

W pracy tej starano się ustalić, czy istnieje możliwość sztucznej infekcji żywych drzew i martwego drewna brzozowego grzybnią I. obliquus pozyskaną w warunkach naturalnych i wyhodowaną w warunkach laboratoryjnych. Badano również stosunki biotyczne pomiędzy $I$. obliquus a wybranymi grzybami występującymi na brzozie, w celu ustalenia w jakim stopniu stanowią konkurencję i czynnik ograniczający dla wzrostu grzybni I. obliquus.

W 1999 roku zaszczepiono 30 żywych brzóz oraz 15 wałków brzozowych inokulatami z grzybnią na terenie Nadleśnictwa Mińsk. Po 3 latach zlikwidowano doświadczenie dotyczące wałków. Okazało się, iż martwe drewno brzozowe było naturalnie kolonizowane przez pospo lite gatunki saprotroficzne: Trametes versicolor, Stereum hirsutum, Bjerkandera adusta. Pozy skano również 2 drzewa żyjące (z 30 zaszczepionych). W kabinie szczepień z przywiezionych fragmentów drewna wyjmowano pierwotne inokulum oraz pobierano wycinki z odległości $1 \mathrm{~cm}$ od miejsca inokulacji, które następnie kładziono na pożywkę agarowo brzeczkową w płytkach Petriego. W przypadku zauważalnej zgnilizny wycinki drewna pobierano z kolejnych odległości wzdłuż osi pnia, co $2 \mathrm{~cm}$. W ściętych drzewach próbnych oraz wałkach brzozowych nie stwierdzono obecności grzybni I. obliquus. Próby sztucznego wprowadzania I. obliquus do środowiska naturalnego napotykają na duże problemy związane z silną konkurencją innych grzybów rozkładających drewno brzozowe oraz prawdopodobnie z innych powodów, nie do końca rozeznanych w tych doświadczeniach. Stwierdzono, iż w pniach ściętych drzew prób nych wytworzyła się wyraźna, ciemno zabarwiona fałszywa twardziel o zarysie gwiaździstym, której ramiona pokrywały się z miejscami wykonania nawiertów.

Wyniki badań laboratoryjnych dotyczące indywidualnych efektów biotycznych pomiędzy różnymi grzybami rozkładającymi drewno brzozowe pokazują, iż I. obliquus jest gatunkiem ograniczanym.

Przeprowadzone badania wskazały, iż zastosowane metody nie dają praktycznych możli wości czynnej ochrony Inonotus obliquus. Należy poszukiwać innych metod sztucznego szcze pienia brzóz. 